\title{
INTEGRASI NILAI-NILAI SPIRITUAL DALAM MATERI RELASI
}

\author{
Oleh: \\ Kusno $^{1)}$, Marsigit ${ }^{2)}$ \\ 1)Program Studi Pendidikan Matematika, Universitas Muhammadiyah Purwokerto \\ ${ }^{2)}$ Program Studi Pendidikan Matematika, Universitas Negeri Yogyakarta \\ kusnoump@gmail.com ${ }^{1)}$
}

\begin{abstract}
:
The purpose of this study was to express spiritual values in mathematic learning of Relations. This study was a qualitative research with a case study method with a grounded theory approach. The research subjects were mathematics teachers and 2ndstudents of MTs 1 Banyumas who were selected using purposive sampling technique. Methods of data collection through in-depth interviews, observation, and document studies. Data were analysed with inductive method and discribed with narative. The results showed that the spiritual values in relation material can be extracted from the ontological concept of relations. Spiritual values in Relationships philosophically contribute to the development of the structure of human life.
\end{abstract}

Keyword: Integration, Relationships, Spiritual Value

\section{PENDAHULUAN}

Pendidikan holistik dalam era globalisasi menjadi isu yang menarik bagi dunia pendidikan di Indonesia.Robert Einstein (1982) mengungkapkan bahwa agama tanpa ilmu buta dan ilmu tanpa agama lumpuh.Reimer (1979) merekomendasikan integrasi nilai-nilai moral, spiritual dalam kurikulum sekolah.Nilai-nilai moral dan spiritual perlu diintegrasikan dalam pembelajaran matematika(Kusno, 2017) agarmenjadi lebih bermakna dalam kehidupan.Ini merupakan tantangan yang cukup berat dalam pembelajaran matematika karena mayoritas guru matematika tidak memilikipemahaman penuh tentang peran spiritual, moral, sosial, dan culture (SMSC) dalam matematika.(Agashi, Pius, \& Enemali, 2015).

Tujuan penelitian ini adalah untuk mengungkap nilai-nilai spiritual dalam pembelajaran matematikadengan strategi VCT di Madrasah Tsanawiah (MTs)Negeri 1 Banyumas pada materi Relasi dan Fungsi. Manfaat penelitian iniadalah menguatkan teori integrasi dalam pendidikan holistik sebagai upaya membangun kesadaran sebagai makhluk Tuhandan makhluk sosial, serta menjadikan materi matematika menjadi lebih bermakna dan lebih mudah terpateri dalam pemahaman peserta didik. Dalam hal ini nilai-nilai spiritual digali dari objek matematika, atau objek matematika dikembangkan dari aktivitas spiritual, sehingga proses matematisasiterjadi secara simultan sejalan dengan proses internalisasi nilai. Hal ini dimaksudkan agar matematika dapat berkontribusi membangun kesadaran spiritual yang 


\section{AlphaMath \\ Journal of Mathematics Education, 4(1) Mei 2018}

hakiki karena berlandaskan rasional yang kuat, atau aktivitas spiritual dapat berkontribusi dalam pengembangan konsep matematika sehingga lebih bermakna dalam kehidupan.

Nashr (2008) menyatakan bahwa nilai-nilai spiritual dalam diri seseorang adalah kekuatan rohaniah yang mendorong orang tersebut bertindak sempurna sesuai dengan kehendakNya.Sebagai implikasinya adalah timbulnya kesadaran akan eksistensi diri sebagai hamba Allah dan tanggungjawabnya dalam kehidupan yang dapat ditunjukkan dengan sifat rendah hati, patuh dan semangat pengabdian. Spiritual (Aldarabah, Almohtadi \& Mohamed, 2014) adalah realisasi dari tauhid yang berbasis pada kesadaran kepada Ilahi. Sebagai implikasinya adalahmeyakini keagungan dan kehadiran Ilahi di setiap aspek kehidupan yang dapat ditunjukkan dengan sifat yakin, jujur, ihsan, dan rasa malu. Menurut Giacalone \& Jurkiewicz (2003) spiritual terkait dengan motivasi individu dalam mencari makna dan tujuan hidupnya. Hal ini dapat ditunjukkan dengan pemilihan aktivitas hidup yang bermanfaat, meninggalkan perbuatan yang sia-sia, rasa ingin tahu, dan menginginkan perubahan yang lebih baik. Menurut Tobroni (2010), nilai-nilai spiritual lebih membimbing individu pada perilaku etis, benar dan jujur karena semuanya harus dipandu dengan kriteria Ilahi, menjadi kontrol yang kuat bagi individu untuk selalu tunduk dan patuh terhadapNya. Hal ini sesuai dengan Huda \& Kartanegara (2015) yang menyatakan bahwa nilai spiritual merupakan nilai karakter inti sebagai dasar karakter individu yang baik, untuk melengkapi manusia dengan kualitas dan sifat-sifat mulia. Sebagai implikasidari pemahaman ini adalah timbulnya keyakinan adanya misi kesucian dalam hidup yang dapat ditunjukkan dengan sifat pemaaf, suka meminta maaf, beristighfar, merefleksi diri dan bertaubat. Hamzah, Isa \& Janor (2010) menegaskan bahwa nilai-nilai spiritual dalam pendidikan berfungsi untuk membawa manusia lebih dekat dengan Allah SWT. dan mengembangkan kesadaran diri terhadap tanggung jawab manusia sebagai khalifah. Di samping itu, Dalmeri \& Ratono (2016) menyatakan bahwa spiritualitas menekankan pada kesalehan individu yang menghasilkan kepuasan pribadi dan memenuhi kebutuhan pribadi akan hubungan dengan Sang Pencipta.Menurut pandangan ini kepuasan dan kebahagiaan tertinggi hidup bukan pada kebendaan namun pada penyatuannya terhadap kehendak Ilahi.Hal ini dapat ditunjukkan dengan sifat ridla, syukur, dzikir, dan berdoa.Nilai-nilai spiritual merupakan jiwa dari pendidikan yang dapat digali dan dikembangkan dari matematika sekolah sebagai aktivitas manusia.

Matematika sekolah oleh Ebbutt dan Straker (1995) dinyatakan sebagai (1) kegiatan penelusuran pola dan hubungan yang menuntut penyelidikan pola-polamelaluiberagam 
percobaan, (2) kreativitas yang memerlukan imajinasi, intuisi dan penemuan, (3) kegiatan problem solving untuk merangsang, mengembangkandan memecahhkan masalah matematika (4) alat komunikasi yang mendorong peserta didik mengenal, membuat dan menjelaskan contoh sifat matematika.Menurut Soedjadi (1999), matematika sekolah adalah bagian dari materi matematika yang dipilih dengan orientasi kepada kepentingan kependidikan dan perkembangan IPTEK. Perbedaan matematika sekolah dan matematika sebagai ilmu terletak pada penyajian, pola pikir, keterbatasan semesta, dan tingkat keabstrakannya.

Rusman (2009) menegaskan bahwa materi ajar hendaknya disajikan secara kreatif sedemikian sehingga mampu: (1) mendorong peserta didik mewujudkan gagasan-gagasan baru, (2) menanamkan sikap kejujuran dan keadilan, (3) menuntut peserta didik melakukan karya dan penyaluran bakat akademisnya secara baik, (4) memanfaatkan lingkungan secara bertanggungjawab, (5) membangun komunikasi dan sinergi secara efektif dan santun yang mencerminkan harkat dan martabatnya sebagai mahluk Tuhan, dan (6) enumbuhkembangkan sikap ilmiah dalam mensikapi perbedaan menurut cara pandang tertentu. Dalam pengembangan materi ajarmatematika, harus memperhatikan objek-objek langsung (konsep, fakta, prinsip, dan keterampilan) maupun tak langsung (pembuktian teorema, pemecahan masalah, belajar bagaimana belajar, pengembangan intelektual, bekerja secara individu, bekerja dalam kelompok, dan sikap positif terhadap matematika). Kedua objek tersebut hendaknya dapat berjalan selaras, serasi dan seimbang. Jika sasaran belajar matematika hanya pada objek langsung saja maka matematika akan berubah menjadi kering dari konteks, kurang bermakna (meaningless) dan sulit tersimpan dalam long-term memory peserta didik (Matlin, 2003). Demikian sebaliknya bahwa objek tak langsung matematika juga tidak boleh diabaikan karena hal itu akan menghilangkan ruh yang terkandung dalam materi matematika.

Pada pendidikan holistik pembelajaran matematika hendaknya efektifmendukung pendidikan karakter sekaliguspemahaman konsep matematika. Menurut Vygotsky (1978), pembelajaran yang efektif meliputi tiga hal utama yakni: (1) mengarah pada perkembangan peserta didik, (2) dikembangkan melalui setting pemecahan masalah, dan (3) berfokus pada upaya membantu peserta didik mencapai potential development mereka. Untuk mencapai pembelajaran efektif perlu: (1) tingkatkan sensitivitas bahwa peserta didik terlibat secara aktif dalam setting belajar yang dikembangkan, (2) ciptakan problem solving interaktif yang mengarah pada proses belajar, (3) sajikan soal-soal yang bersifat menantang, (4) gunakan on-going assessment untuk memonitor pembelajaran, (5) ciptakan kesempatan 
bagi peserta didik untuk menampilkan kemampuan berfikir tingkat tingginya, (6) beri dorongan dan kesempatan peserta didik menampilkan berbagai solusi serta strategi berbeda pada penyelesaian masalah, (7) tingkatkan komunikasi, yakni dengan mendorong peserta didik memberikan penjelasan serta jastifikasi pemikiran mereka, (8) gunakan berbagai variasi strategi mengajar dan belajar, dan (9) upayakan menelusuri hal-hal yang belum diketahui peserta didik dalam proses peningkatan potensial mereka sesuai perkembangan intelektualnya.

Pada pembelajaran matematika dikembangkan pengalaman belajar dengan strategi Value Clarification Technique (VCT) yaitu teknik pembelajaran yang dapat membantu peserta didik mencari atau menentukan nilai yang dianggap baik dalam menghadapi suatu permasalahan melalui proses menganalisis nilai yang sudah ada dan tertanam dalam diri peserta didik. Teknik ini pertama kali diperkenalkan oleh Douglas Superka (1976). Beberapa pilihan strategi VCT yang bisa dikembangkan dalam tahap ini: (1) pendekatan evokasi yaitu peserta didik didorong untuk menyatakan ide-idenya, tanggapannya, perasaannya, secara terbuka dan penuh kebebasan, (2) pendekatan sugesti terarah yaitu siswa secara pelan-pelan digiring untuk mengarah pada suatu kesimpulan dan menerima nilai tertentu, (3) pendekatan kesadaran (awareness) yaitu melalui suatu kegiatan peserta didik diberi kesempatan untuk mengamati dan dituntun untuk mengklarifikasi dirinya sendiri, (4) pendekatan kejelasan moral (moral reasoning) yaitu guru mengungkapkan dilema kepada siswa dan memint terlibat dalam dilema itu melalui dialog.

Lebih jauh Iyer (2013) mengemukakan pendekatan yang dapat dipilih sebagai alternatif dalam pembelajaran nilai sebagaimana dilangsir oleh UNESCO dalam pengembangan pendidikan karakter sebagai berikut, yaitu: (1) Telling (proses pengembangan nilai yang memungkinkan siswa mendapatkan gambaran nilai yang jelas dari suatu situasi yang dinarasikan, (2) Inkulkasi (pendekatan kearah menanamkan norma-norma sistem nilai pribadi), (3) Persuading (proses meyakinkan siswa untuk memenerima nilai tertentu dan berperilaku sesuai dengan nilai yang diterimanya), (4) Modeling (seorang individu berperan sebagai pelaku dari nilai-nilai yang diterimanaya), (5) Role playing (bermain peran), (6) Simulasi (pebelajar berpura-pura berada pada situasi tertentu untuk meniru nilai-nilai tertentu), (7) Problem solving (pendekatan dilematika yang ditampilkan agar siswa bertanya kepada mereka bagaimana keputusan yang diambil), (8) Diskusi sistuasi, cerita, gambar (teknik ini menuntut siswa menjelaskan dengan sengaja/dengan bebas secara detail dalam 
pelajaran), (9) Mengkaji biografi tokoh besar (pendekatan ini menggunakan kehidupan orang besar sebagai subjek materi untuk mencoba menimbulkan/mendatangkan kebutuhan baik dan pemikiran yang berharga sebagai ajang perlombaan), (10) Moralizing (aktivitas restrukturisasi pengalaman sosial seseorang melalui analisis rasional), (11) Klarifikasi nilai (pebelajar merilis kekayaan kecakapan siswa sebagai proses keyakinannya berperilaku sesuai dengan apa yang diyakininya).

Matematika adalah bidang ilmu yang memiliki berbagai nilai di dalamnya, (Dede, 2006), yang perlu dikembangkan secara inovatifsehingga lebih bermakna dalam hidup. Materi ajar matematika perlu dikembangkan dengan pendekatan afektif, keyakinan, sikap dan emosional (Zan, Brown, Evan, \& Hannula, 2006), antara lain dapat memberikan pesan-pesan spiritual, yang menjadi ide dasar pengembangan matematika (Krajewski, 2016) selanjutnya. Bahan ajar matematika lebih bermakna dalam kehidupan peserta didik bila mampu mengembangkan pemikiran secara mendalam untuk memicu spiritualitaspeserta didik melalui literasi matematika khususnya literasi spasial. Literasi spasial merupakan kemampuan yang mendukung pemahaman dunia (3D) dimana kita tinggal dan bergerak (De Lange, 2006).

Meiyappan (2017) menegaskan bahwa dalam proses integrasi, peserta didik didorong untuk menggali lebih dalam pemahaman mereka tentang matematika dan bagaimana kaitannya dengan dunia di sekitar mereka. Zein (2014) mengemukakan bahwa integrasi nilai-nilai spiritual dan matematika dapat dilakukan melalui interkoneksi, mengacu pada perspektif ontologis, epistemologis dan ontologis. Dasar konseptual dan meta matematis yang dipilih merupakan kreativitas matematika (Setia, 2008), sebagai titik awal meta-prosesaktivitas manusia yang menghasilkan bahan ajar matematika baru, yang terintegrasi.

Strategi integrasi nilai-nilai spiritual dalam matematika dapat dilakukan melalui modelling, analogi, ilustrasi, ataupun dasar filosofis (Kusno, 2013). Modelling adalah teknik integrasi nilai melalui sosok panutan yang tergambar dalam steam cerita. Modelling merupakan bentuk matematika model yang tidak hanya memodelkan matematika ke dalam bentuk matematis, namun juga memodelkan performansi seseorang atas kebaikan nilai-nilai spiritual yang dianutnya.Ilustrasi adalah teknik pembentukan nilai spiritual melalui penggambaran yang bersifat konkrit, dapat dilihat, diamati, disimulasikan bahkan diperankan.Filosofis merupakanteknik pembentukan nilai spiritual dengan menggunakan pijakan yang penuh makna baik yang tersimpan dalam bentuk simbolis, maupun bahasa dalam rangkaian ceritera. 
Menurut Masduki, Khatimah, Sutarni, \& Toyib (2015) internalisasi nilai dalam integrasi dapat dilakukan melalui Infusi (dalam mengajarkan matematika, guru menekankan aspek nilai yang ada dalam materi), Analogi (dalam mengajarkan matematika, guru melakukan analogi nilai kebaikan), Narasi (mengajarkan matematikamelalui kisah-kisah berkaitan dengan matematika dan matematikawan untuk diambil hikmahnya), Uswah Hasanah (dalam mengajarkan matematika, guru menunjukkan perilaku yang patut dicontoh terkait matematika misalnya kejujuran, kesungguhan, ketepatan, ketaatan, dan ketelitian). Kusmaryono \& Maharani, (2017) menyarankan agar para pendidik dan guru membangun pendekatan infusi untuk mempromosikan citra matematika yang lebih manusiawi karena dapat meningkatkan minat belajar siswa, dan dapat mendorong perhatian guru (Hudha, Ekowati \& Husamah, 2014) terhadap karakter peserta didik. Dalam infusi, nilai-nilai yang dikembangkan disesuaikan dengan karakteristik materi ajar sehingga internalisasi nilai bersamaan dengan proses matematisasi. Misalnya materi aljabar untuk memberikan pesan moral berupa nilai-nilai akhlak, tolong menolong, rasa hormat perhatian (Rosimanidar, 2016), materi himpunan untuk mengajarkan aqidah dan nilai-nilai moral (Nihayati, 2017), barisan bilangan pecahan untuk memberikan pesan spiritual berupa ketundukkan kepada Allah swt, dan konsep limit untuk memberikan pesan spiritual berupa kemahaesaan Allah (Maarif, 2015).

\section{METODE PENELITIAN}

Penelitian ini merupakan penelitian kualitatif dengan metodestudi kasus dan pendekatan Teori Grounded (TG). Menurut Charmaz (2000), TG merupakan metode penelitian yang menggunakan petunjuk-petunjuk sistematis dalam pengumpulan dan analisis data dengan maksud untuk membangun kerangka teori yang dapat menjelaskan data yang terkumpul. Hal ini diperkuat oleh Creswell (2015) bahwa TG cocok digunakan bila tidak didapatkan teori untuk menjelaskan atau memahami proses. Penggunaan metode ini juga didasarkan atas pertimbangan bahwa penelitian bukan untuk melakukan pengujian terhadap teori atau memulai penyelidikan dengan dasar teori tertentu lalu membuktikannya, melainkan ingin mengembangkan teori yang terkait dengan pengintegrasian nilai-nilai spiritual Islam dalam pendidikan matematika.

Lokasi penelitian ini adalah di kelas 2 MTs Negeri 1 Banyumas dengan alasan bahwa Madrasah tersebut mengembangkan nilai-nilai spiritual dalam pendidikan, dan adanya ketersediaan data penelitian. Subjek penelitian ditetapkan berdasarkan pengalaman responden 
dalam mengikuti pelatihan yang relevans, peran serta responden dalam organisasi sekolah, energik, inovaif dan komunikatif. Subjek dan pendamping penelitiannya adalah kepala madrasah, guru-guru matematika kelas 2 dan peserta didik kelas 2. Penelitian dilakukan melalui tahap-tahap: (1) riset pendahuluan, (2) seleksi data yang akan dikaji, (3) pengumpulan data, (4) analisis data (5) Sintesis dan generalisasi.

Teknik pengumpulan data dalam penelitian ini yaitu wawancara semi terstruktur, observasi, dan telaah dokumen. Wawancara semi terstruktur digunakan untuk mengumpulkan data tentang fenomena (gejala-gejala yang ada dalam pemikiran, gagasan, perasaan, cita-cita, maupun pengalaman) dari guru, kepala Madrasahdan peserta didik tentang integrasi nilai-nilai spiritual dalam pembelajaran matematika sesuai dengan kapasitasnya masing-masing sebagai kontrol sekaligus penguatan informasi yang digali dari data observasi. Hasil wawancara segera dituliskan kembali (ditulis dalam format teks atau di tangkap dalam bentuk identifikasi yang jelas dari sub elemen). Muhadjir (2016) menyarankan agar dalam penulisan kembali mencari peluang waktu dimana ingatan masih segar dan sedang tidak ada bersama dengan subyek responden. Observasi digunakan untuk mengumpulkan informasi yang lebih menyeluruh terkait dengan proses integrasi nilai-nilai spiritual dalam pembelajaran matematika. Adapun sumber-sumber informasi yang akan digali melalui observasi adalah fakta (dokumen) dan peristiwa (aktivitas guru dan siswa) selama pembelajaran yang berupa perilaku guru, interaksi belajar mengajar, dan perilaku peserta didik yang terkait dengan nilainilai spiritual. Sebelum observasi, peneliti menyiapkan lembar observasi yang berisi indikator perilaku guru, proses pembelajaran dan perilaku peserta didik yang dibuat dalam sebuah kisikisi. Dokumen digunakan untuk menggali data historis tentang proses kebijakan pendidikan yang terkait langsung maupun tidak langsung dengan pengembangan nilai-nilai spiritual dan pelaksanaan pendidikan, terutama dokumen kurikulumpada mata pelajaran matematika.

Validasi temuan dalam penelitian menggunakan validasi kualitatif menurut Lincoln \& Guba (1985), yang meliputi beberapa kriteria, yakni: (1) Credibility, yang digunakan untuk mengatasi kompleksitas data yang tidak mudah untuk dijelaskan oleh sumber data, peneliti harus berpartisipasi aktif dalam melakukan tindakan, berada di latar penelitian sepanjang waktu penelitian guna menghindari adanya bias dan persepsi yang salah, (2) Transferability, merupakan konsep validitas yang menyatakan bahwa generalisasi suatu 


\section{AlphaMath \\ Journal of Mathematics Education, 4(1) Mei 2018}

penemuan penelitian dapat berlaku atau diterapkan pada konteks lain yang berkarakteristik sama.(3) Dependability, untuk menunjukkan stabilitas data, peneliti memeriksa data dari beberapa metode yang digunakan sehingga tidak ada perbedaan antara data yang satu dengan yang lain, (4) Confirmabilit yuntuk menunjukkan netralitas dan objektivitas data, peneliti dapat menggunakan jurnal guna melakukan refleksi terhadap data yang dikumpulkan.

Teknik analisis data mengikuti langkah-langkah yang dikemukakan Creswell (2015) yaitu meliputi: (1) mempersiapkan data baik data mentah, transkripsi, data lapangan, gambar dan sebagainya, (2) mengolah dan memepersiapkan data untuk dianalisis seperti transkrip wawancara, menscanning materi, memilah-milah dan menyusun data sesuai dengan sumber informasi, (3) membaca keseluruhan data untuk menangkap gagasan umum yang terkandung dari informasi partisipan, (4) menganalisis lebih detil dengan mengkoding data. Coding merupakan proses mengolah materi atau informasi menjadi segmen-segmen tulisan sebelum memaknainya, (5) terapkan proses koding untuk mendiskripsikan setting, kategori-kategori, dan tema-tema yang akan dianalisis. Kemudian membuat analisis yang lebih kompleks dengan cara: (1) peneliti membaca seluruh deskripsi; (2) peneliti mensarikan pernyataanpernyataan yang signifikan dari tiap deskripsi; (3) pernyataan dirumuskan menjadi maknamakna yang dikelompokkan ke dalam tema-tema, dan (4) peneliti mengintegrasikan tematema menjadi deskripsi naratif.

Teknik analisis data yang dipakai dalam penelitian ini adalah analisis komparatif terhadap fakta-fakta replikatif. Dari komparasi fakta-fakta tersebut dapat dibuat konsep atau setidaknya abstraksi teoretisnya, kategori, dan generalisasi. Dengan data komparasi dan analisis eksplisit (tidak menguji hipotesisnya secara langsung) maka dapat mengarah ditemukannya keragaman teori substansi untuk suatu jangkauan tertentu yang selanjutnya dapat dikembangkan menjadi teori formal. Glaser \& Strauss (Noeng, 2016) menyatakan bahwa teori substanti ditemukan dan dibentuk untuk daerah substantif tertentu, sedangkan teori formal ditemukan dan dibentuk untuk kawasan kategori konseptual teoritis.

\section{HASIL DAN PEMBAHASAN}

Hasil wawancara dengan Istiqomah (Waka Kurikulum) MTs Negeri 1 Banyumas tanggal 30 Januari 2018 bahwa semua kegiatan pembelajaran di Madrasah tetap semaksimal mungkin dikaitkan dengan nilai-nilai spiritual. Kaitan dengan keterbatasan waktu dan muatan kurikulum yang sangat banyak, maka kreativitas guru dalam mengintegrasikan nilai-nilai 
spiritual dalam pembelajaran sangat penting asal jangan menyimpang dari apa yang sudah ditetapkan.

Integrasi nilai-nilai spiritual dalam pembelajaran tidak lepas dari motivasi instrinsik seorang guru sebagai pendidik sebagaimana diungkapkan oleh guru sebagai berikut:

Motivasi saya yang pertama untuk menambah ilmu dan mencari pengalaman, juga ingin mempunyai kebaikan yang mengalir walaupun nanti kita sudah tidak ada atau tutup usia. Sebagai bentuk pengabdian kepada Allah dengan niat ibadah, yang mengamalkan amar makruf nahi munkar

Strategi untuk mengintegrasikan nilai-nilai spiritual yang dilakukan dalam pembelajaran matematika diungkapkan oleh guru sebagai berikut:

Memberikan materi matematika dengan mengambil konteks kehidupan spiritual dalam kehidupan sehari-hari agar lebih bermakna dan menjadikan matematika sebagai landasan filosofis dalam menghayati nilai-nilai spiritual.

Hal ini menunjukkan bahwa strategi guru dalam mengintegrasikan nilai-nilai spiritual dalam pembelajaran matematikaadalah sebagai berikut: (1) mengambil konteks kehidupan seharihari agar matematika lebih bermakna bagi peserta didik, dan menjadikan matematika sebagai landasan filosofis dalam menghayati nilai-nilai spiritual, (2) menyisipkan ayat, atau hadits yang relevan dalam pembahasan materi tertentu sebagai bentuk penguatan terhadap nilai-nilai spiritual yang bersesuaian dengan nilai-nilai matematika, dan (3) juga memanfaatkan kisahkisah inspiratif, agar selalu ingat dan bersyukur kepada Allah SWT.

Nilai-nilai spiritual yang terkandung dalam materi ajar matematika berbeda-beda sesuai dengan topik masing-masing. Misalnya pada konsep Relasi terdapat nilai ukhuwahantar sesama mahkluk ciptaan Tuhan dan pada konsep Fungsi terdapat nilai spiritual bersyukur dan tawakal sebagaimana dinyatakan guru bahwa "Dalam konsep relasi ada aturan yang menginspirasi bahwa hidup itu adalah pilihan". Dalam materi Relasi dan fungsi terkandung falsafah pendidikan yang sangat penting bagi kehidupan manusia khususnyan untuk menanamkan nilai-nilai spiritual.

Urgensi integrasi nilai-nilai spiritual dalam pembelajaran matematika

1) Bagi saya sendiri untuk menguatkan keyakinan bahwa dibalik pengetahuan matematika ada keagungan kemahabesaran ilahi terus juga untuk memudahkan proses berpikir yang holistik, juga sebagai bahan ajar yang menarik untuk menginspirasi ide-ide yang lebih komprehensif dan inovatif 


\section{AlphaMath \\ Journal of Mathematics Education, 4(1) Mei 2018}

2) Untuk menguatkan keyakinan bahwa ternyata dibalik pengetahuan matematika ternyata ada keagungan dan kebesaran ilahi, memberikan kontribusi pada pembentukan karakter peserta didik terutama dalam menanamkan nilai-nilai islam yaitu nilai akidah, dan nilainilai akhlak

Adapun urgensinya dalam kehidupan adalah untuk menguatkan keyakinan bahwa dibalik pengetahuan matematika ada keagungan atau kemahabesaran Ilahi, untuk memudahkan proses berpikir yang holistik, sebagai bahan ajar yang menarik untuk menginspirasi ide-ide yang lebih komprehensif dan inovatif, menanamkan nilai-nilai spiritual terutama nilai akidah, dan nilai-nilai akhlak.

Hasil wawancara dengan peserta didik diperoleh data bahwa cara guru matematika mengembangkan pembelajaran menarik minat belajar, mudah dicerna dan dapat menyentuh emosional peserta didik, karena dalam pembelajarannya guru menginspirasi nilai-nilai spiritual seperti berbuat baik dengan sesama, kejujuran dan mengaitkan pesan-pesan dalam Al-Quran atau Hadits. Secara ringkas hasil wawancara terhadap peserta didik sebagai berikut:

1) Guru dalam mengembangkan pembelajaran dapat menarik minat belajar dan kesadaran, menarik dan menyentuh perasaan. Guru menjadikan nilai-nilai spiritual sebagai wahana dakwah dalam pembelajaran matematika, misalnya berbuat kebaikan terhadap sesama, harus jujur dan lurus dan mengaitkan Al-Quran dalam pelajaran

2) Cara guru mengintegrasi nilai-nilai spiritual islam dalam pembelajaran matematik yaitu dikaitkan dengan materi dan metode pembelajaran

Hasil observasi terhadap pembelajaran, diperoleh bahwa pembelajaran matematika pada materi Relasi dilakukan secara realistik melalui konteks silaturrahiim. Aktivitas yang dipilih adalah kegiatan bertamu yang membawa misi saling memaafkan, menghargai dan memuliakan. Didalamnya ada adegan menjamu tamu yang secara filosofis memberikan landasan berpikir tentang konsep Relasi dan dari konsep relasi peserta didik diajak untuk menentukan simbol dari konsep yang telah disepakati. Nilai-nilai spiritual terintegrasi dalam setiap tahapan matematisasi baik pada konteks, aktivitas, konsep maupun simbol yang disepakati bersama.

Sesuai data hasil observasi dan wawancara, ada infusi nilai-nilai spiritualdalam pembelajaran matematika yang tergambar secara eksplisit maupun implisit. Secara eksplisit nilai-nilai spiritual dalam kegiatan pendahuluan berupa pujian kepada Allah swt, melalui doa, dzikir asmaulhusna dan membaca Al-Quran ayat pilihan sesuai dengan materi yang dipelajari,dan 
secara implisit dalam penyajian materi Relasi melalui konteks silaturrahiimdalam bentuk aktivitas bertamu yang memperagakan sikap saling memaafkan, menghargai, dan memuliakan.Dalam pembelajaran ini peserta didik diberi kesempatan untuk mengamati dan dituntun untuk mengklarifikasi dirinya sendiri (pendekatan awareness) dan menurut strategi VCT, tamu berperan sebagai model dari nilai-nilai yang diterimanya (modelling).

Konsep dasar relasi dikonstruksi secara kreatif dan tergambar dalam prosesi penyajian hidangan buah-buahan yang menunjukkan adanya hubungan antara tamu dan hidangan yang disajikan. Ketika tuan rumah mempersilahkan tamu untuk menikmati hidangan makanan, maka tamu berhak untuk memilih hidangan sesuai dengan apa yang disukai, bisa satu, bisa lebih dari satu bahkan bisa terjadi ada tamu yang tidak menikmati sajian dengan alasan tertentu. Hal ini menunjukkan sifat hubungan yang terjadi dalam relasi antara tamu dan hidangan. Aktivitas ini menggambarkan sebuah pola hubungan antara tamu dan hidangandengan aturan tamu menikmati hidangan yang disajikan. Selanjutnya melalui matematisasi horisontal dikonstruksi pengertian relasi dengan menggunakan simbol yang lazim dan disepakati bersama antara guru dan peserta didik. Dalam hal ini tamu merupakan derah asal yang disebut dengan domain dan disimbolkan dengan A dan dan makanan merupakan daerah kawan yang disebut dengan kodomain dan disimbolkan dengan $B$ sehingga relasi antara A dengan B dinyatakan dengan ARB atau R:A B.

Nilai-nilai spiritual terungkap dalam tahapan-tahapan aktivitas peserta didik dalam mengkonstruksi pemahaman materi melalui konteks silaturrahiim sebagai pengalaman belajar. Kegiatan silaturrahiim dipilih menjadi konteks dalam mengkonstruksi pemahaman tentang relasi karena core dari silaturrahiim adalah relasi, dan nilai-nilai spiritual banyak yang melekat pada kegiatan silaturrahiim. Silaturrahiim yang berarti menyambung tali persaudaraan dalam hal ini ditunjukkan dengan prosesi bertamu yang memerankan akhlak mulia yaitu sikap saling memaafkan dan memuliakan, sehingga menjadi kesempatan yang tepat bagi guru untuk menyampaikan pesan-pesan spiritualnya "Sesungguhnya orang-orang mukmin itu bersaudara, karena itu damaikanlah antara kedua saudaramu (yang berselisih) dan bertakwalah kepada Allah agar kamu mendapat Rahmat. "(Qs Al-Hujurat ayat 10).

Aktivitas menjamu tamu yang ditunjukkan dengan menghidangkan buah-buahan, dengan tersenyum, menyapa, dan mempersilahkan tamu menikmati hidangan, memberikan pesan spiritual untuk memuliakan tamu sebagaimana sabda Nabi saw "Barangsiapa yang beriman kepada Allah dan hari akhir maka muliakan tamu (HR. Bukhari)”. Sementara aktivitas tamu 
memilih hidangan makanan yang disukai disamping memberikan landasan pemahaman tentang konsep dasar relasi juga memberikan pesan filosofis bahwa hidup adalah sebuah pilihan.

Dalam pandangan guru (Tabel 1), nilai-nilai spiritual dalam pembelajaran matematika menjadikan materi matematika lebih bermakna, peserta didik lebih memahami landasan filosofisnya karena dibangun dari kehidupan sehari-hari peserta didik. Selain itu materi matematika dapat menjadi wahana untuk mengingat keagungan Allah swt serta pesan-pesan spiritual lainnya yang sangat diperlukan dalam kehidupan. Integrasi nilai-nilai spiritual dapat dijadikan inspirasi dalam pengembangan bahan ajar yang menarik untuk menginspirasi ideide kreatif, dan inovatif untuk membangun matematika baru yang holistik. Dalam pandangan peserta didik integrasi nilai-nilai spiritual dalam pembelajaran matematika lebih menarik, materi pelajaran lebih mudah dicerna, dan dapat memberikan pesan dakwah yang menyentuh perasaan (kesadaran emosional).

Nilai-nilai spiritual dalam matematika khususnya dalam materi Relasi digali dari konteks, aktivitas, konsep dan simbol. Dalam hal ini konteks yang dipilih untuk kepentingan pengembangan konsep adalahsilaturrahiim karena silaturrahiim adalah core dari Relasi yang memuat banyak nilai-nilai spiritual penting untuk penguatan karakter peserta didik. Aktivitas yang dipilih dari konteks silaturrahiim dalam hal ini adalah kegiatan bertamu yang ditunjukkan dengan sikap saling memaafkan, memuliakan, menghidangkan makanan, menyantap hidangan makanan yang disukai. Aktivitas tersebut merupakan bentuk modeling yang pantas diteladani peserta didik. Simulasi memilih hidangan makanan yang diperankan masing-masing kelompok belajar dalam pembelajaran matematika disamping dapat merefleksikan pemahaman tentang konsep relasi, juga dapat memberikan pesan demokrasi yang dapat menyentuh sensasi peserta didik.

Konsep yang dikembangkan adalah Relasi sebagai sumber inspirasi nilai-nilai spiritual. Relasi yang secara konseptual merupakan aturan yang menghubungkan dua himpunan, secara filosofis dapat memberikan pesan kepada manusia bahwa setiap hubungan yang dilakukan baik dengan Tuhannya sebagai hamba, maupun dengan lingkungannya sebagai makhluk sosial, ada aturan yang harus dihormatidan ditegakkan. Konsep Relasi secara filosofis juga dapat menggambarkan kepemimpinan yang relasional, karena dalam konsep Relasi ada unsur Domain dan Kodomain sebagai bentuk komunitas atau entitas, ada ide-ide inovatif berupa 
aturan pemasangan kedua komunitas atau entitas sehingga menyebabkan perubahan positif, yaitu kebermaknaan dalam hidup. Falsafah kepemimpinan ini menguatkan teori kepemimpinan relasional sebagaimana dikemukakan oleh Smit (2016) di mana sistem sosial di sekolah adalah jaringan interaksi antara berbagai kelompok di dalam sekolah, yang melayani sejumlah tujuan, dengan maksud untuk memfasilitasi arus informasi, yang mencerminkanproses sosialisasi, dan pengalihan nilai-nilai moral.

Fakta yang berupa simbol Relasi yang dinyatakan dengan ARB juga mengandung nilai spiritual. Secara filosofis R yang berarti hubungan memberikan pesan bahwa manusia tidak bisa hidup tanpa adanya hubungan dengan lainnya. Eksistensi manusia karena ada yang menciptakan maka ia berhubungan dengan Tuhan sebagai makhlukNya, hajat hidupnya ditopang oleh masyarakat sehingga harus berhubungan dengan lingkungan sebagai makhluk sosial, bahkan kematiannya tidak mampu mengurusi diri sendiri maka berhubungan dengan sesama.

Konstruksi matematika yang dimulai dari pemilihan konteks, pemilihan aktivitas pengalaman belajar, penarikan konsep dan simbolisasi merupakan matematisasi horisontal yang dapat menghasilkan matematika baru yang bersifat spiritual, material, normatif dan formal. Secara sistematis nilai-nilai spiritual (NS) dalam pembelajaran matematika khususnya dalam materi relasi dan sangat memungkinkan untuk dikembangkan pada materi-meteri yang lain dapat digambarkan dalam bagan berikut:

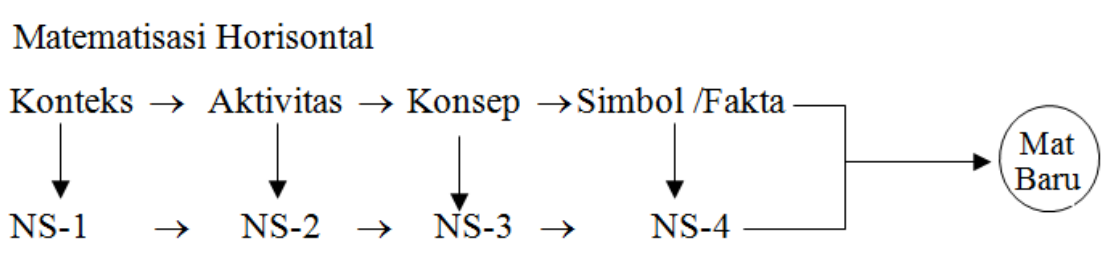

Internalisasi Spiritual

Gambar 1. Model Integrasi Nilai-nilai Spiritual dalam Pembelajaran Matematika

Nilai-nilai spiritual sebagai karakter inti manusia untuk berperilaku etis sangat esensial bagi kehidupan manusia, sehingga harus ditanamkan kepada peserta didik secara tepat sesuai 
dengan perkembangan nalarnya. Demikian juga materi matematika harus dikonstruksi dari kehidupan etis (spiritual) peserta didik agar lebih bermakna dan mudah dipahami. Proses internalisasi nilai-nilai spiritual harus berjalan secara simultan saling menguatkan dengan proses matematisasi sehingga menghasilkan matematika baru yang lebih holistik. Proses matematisasi berjalan mulai dari pemilihan konteks, pemilihan aktivitas atau pengalaman belajar, generalisasi konsep, dan simbol/fakta sehingga melahirkan matematika horisontal yang bersifat material, normatif, dan formal. Setiap tahapan dalam matematisasi horisontal ada nilai-nilai spiritual yang dapat digali untuk kepentingan penguatan pendidikan karakter peserta didik sekaligus menjadi sumber inspirasi untuk memateri pemahaman konsep. Nilainilai spiritual dalam matematika di Madrasah menjadikan pembelajaran lebih menyentuh emosional peserta didik, lebih menarik dan lebih bermakna bagi kehidupan.

Penerapan VCT dalam pembelajaran ini adalah sebagai berikut: Siswa mengamati video dengan adegan bertamu untuk bersilaturrahiim dan permohonan maaf terhadap kesalahan yang tidak disengaja menyinggung perasaan tuan rumah, menyaksikan bagaimana sikap dan kelembutan tuan rumah memberi maaf dan memberikan jamuan buah-buahan serta mentadaburi ayat Al-Quran yang bersesuaian dengan peristiwa tersebut. Hal ini menurut VCT adalah sebuah modelling (tamu dan tuan rumah sebagai sosok yang pantas diteladani karena kebaikan akhlaknya) agar siswa tersugesti memperoleh pesan spiritual hidup santun dan bertanggungjawab sehingga sadar dan berkeinginan untuk meneladaninya (pendekatan kesadaran). Dalam hal ini siswa duduk dalam kelompoknya berdiskusi dan di dorong untuk menuangkan ide-idenya tentang daerah asal dan daerah hasil pada prosesi pemilihan buahbuahan yang disukai tamu masing-masing (pendekatan evokasi). Setiap anggota kelompok berperan sebagai tamu dan tuan rumah (pendekatan role playing) dan berpura-pura memilih hidangan yang disukainya (metode simulasi). Hasil simulasi pemilihan buah-buahan yang disukai dalam kelompok masing-masing, selanjutnya digambarkan di papan tulis dan didiskusikan secara terbuka dalam diskusi kelas untuk mengidentifikasi sifat-sifat hubungan antara domain dan kodomain( teknik ini menuntut siswa menjelaskan dengan sengaja/dengan bebas secara detail dalam pelajaran).Selanjutnya siswa didorong untuk menemukan konsep relasi dengan bahasanya sendiri dan dituntun dengan ayat Al-Quran untuk menemukan falsafah kehidupan yang sesuai dengan konsep relasi, yaitu hidup adalah sebuah pilihan.Ini adalah teknik memateri pemahaman konsep yang lebih bermakna sekaligus menginternalisasi nilai-nilai spiritual agar menjadi orang yang bertanggungjawab dengan pilihannya. 


\section{KESIMPULAN}

Materi Relasi dalam pembelajaran matematika memberikan makna matematis dan makna filosofis. Makna matematis menunjukkan himpunan bagian dari perkalian dua himpunan. Aktivitas penyajian hidangan makanan dapat membantu menggambarkan bagaimana konsep relasi itu dipahami siswa. Konsep relasi ditunjukkan dengan pilihan yang mungkin dapat dilakukan tamu untuk menikmati hidangan tersebut. Konsep Relasi dapat digambarkan sebagai suatu struktur kehidupan, dimana manusia hidup memerlukan orang lain, sehingga menimbulkan kebutuhan untuk berpasangan. Relasi juga dapat menggambarkan suatu pilihan artinya orang hidup selalu dihadapkan pada pilihan. Dengan kata lain secara filosofis hidup adalah pilihan.

\section{DAFTAR PUSTAKA}

Demir, O. (2012). A New Theoritical and Educational Approach. Universteit van AmsterdaAgashi, Pius P. \& Enemali. (2015). Investigation of Mathematics teachers conceptualisation of the spiritual, moral, social and cultural role of mathematics. Journal of Education and Practice, 6(33), 47.

Aldarabah, Almohtadi, R., \& Mohamed, K. 2014. Islamic spirituality practices (isp) of preschool teachers and its influence on teachers' organizational commitment (TOC) in work place. International Journal of Educational Research and Technology, 5(4), 68-75.

Smit, B. 2016. Acase for relational leadership and an ethics of care for counteracting bullying at schools. South African Journal of Education, 36(4), 7.

Charmaz, K. (2000). Grounded Theory: Objectivist and Constructivist Methods. In Denzin, N.K. and Lincoln, Y.S. (eds) Handbook of a Qualitative Research (2nd ed.) Thousand Oaks, CA: Sage, 509-533.

Creswell, J. W. (2015). Penelitian Kualitatif \& Desain Riset. Yogyakarta: Pustaka Pelajar

Dalmeri \& Ratono. (2016). Islamic spirituality movement and its implications on social and political ethics in indonesia. International Journal of Islamic Thought, 9, 16.

Dede. (2006). Mathematics edducational values of college students towards function concept. Eurasia Journal of Mathematic, Science and Technology Education, 2(1), 82.

De Lange. (2006). Mathematical literacy for living from OECD-PISA perspective. Tsukuba Journal of Educationalstudy in Mathematics, 25, 13-25.

Departemen Agama RI. (2006). Al-Quranul Karim Terjemahan Bahasa Indonesia. Kudus: Menara Kudus. 
Ebbutt, S. \& Straker, A. (1995). Children and Mathematics', Mathematics in Primary School, Part I. London: Collins Educational.

Einstein, R. (1982). Ideas and Opinion. New York. Three Rivers Press, 8-9.

Giacalone, R. \& Jurkiewicz, C. (2003). Handbook of Workplace Spirituallity and Organizational Performance. New York. M.E. Sharpe, 46-48.

Huda \& Kartanegara (2015). Islamic spiritual character values of al-zarnăjư's taӂlưm almutaӂallim. Mediterranean Journal of Social Sciences, 6(4), 234.

Hamzah, Isa; \& Janor (2010). Spiritual education development model. Journal of Islamic and Arabic, Education, 2(2), 11.

Kusno. (2017). Analysis of islamic spiritual values in mathematic education. Advances in Social science, education and humanities, 4th Asia Pacific Education Conference (AECON), $109,150$.

Kusno. (2013). The Implementation of KIRI (Collaborative, Inovative, Reflective, And Innovative) learning model for the character education in the mathematics department. Proceeding 1ndAeCon 2013, hal 70.

Krajewski. (2016). Theological metaphors in mathematics. Doi Journal of Studies in Logic, Grammar and Rethoric, 44(57), 13.

Kusmaryono \& Maharani. (2017). Penerapan pembelajaran berkarakter islami pada program PPL mahasiswa pendidikan matematika Unissula Semarang. Suska Journal of Mathematics Education, 3(2), 120.

Lincoln, Y.S. \& Guba, E.G. (1985). Naturalistic Inquiry. Beverly Hills, CA: Sage Publications.

Masduki \& Khotimah. 2015. Integrasi nilai-nilai Islam dalam pembelajaran matematika, sebuah strategi pengembangan karakter peserta didik. Kolokium Penelitian Universitas 2015, ISSN 2407-9189, hal $216-231$

Meiyappan. (2017). Spirituality trough mathematic. International journal of pure and applied mathematis, 114(5), 1-11.

Zein, M. (2014). Axiologyonthe Integrationof Knowledge. Journal Islamand Science, 21(2), 154.

Matlin, M. W. (2003). Cognition. Fifth Edition. Hoboken, New Jersy: John Wiley \& Son, Inc, hal 68.

Maarif, S. (2015). Integrasi matematika dan islam dalam pembelajaran matematika. Jurnal Ilmiah Program Studi Pendidikan Matematika Stkip Bandung, 4(2), 223.

Marsigit. (2015). Revitalisasi matematika. Tersedia dihttp://staffnew.uny.ac.id. Diakses 17 Agustus 2017.

Muhadjir, N. (2016). Metodologi Penelitian Edisi IV. Yogyakarta. Penerbit Rake Sarasin. 
Nasr, H. (2008). Islamic Spirituality. USA: Routledge.

Nihayati. (2017). Integrasi nilai-nilai islam dengan materi himpunan (kajian terhadap ayatayat Al-Quran). Jurnal Edumath. Nihayati, 2017ol 3. No 1. Januari 2013, hal 65.

Reimer, J. (1979). Promoting Moral Growth: From Piaget to Kohlberg. New York: Longman.

Rosimanidar. (2016). Pembelajaran aljabar berbasis nilai-nilai. Jurnal Itqan, 7(1). 140.

Rusman. (2009). Manajemen Kurikulum. Jakarta : PT Raja Grafindo Persada.

Setia, A. (2008). Some upstream research programs for muslim mathematicians: operationalizing islamic values in the sciences through mathematical creativity. Journal Islam \& Science, 6(2), 127.

Soedjadi, R. (1999). Kiat Pendidikan Matematika di Indonesia: Konstatasi Keadaan Masa Kini menuju Harapan Masa Depan. Jakarta: Direktorat Jenderal Pendidikan Tinggi, Departemen Pendidikan dan Kebudayaan.

Tobroni. (2015). Spiritual leadership: a solution of the leadership crisis in islamic education in Indonesia. British Journal of Education, 3(11), 40-53.

Vygotsky (1978). Interaction Between Learning and Development. In Gauvain \& Cole (Eds) Reading On the Development of Children. New York: Scientific American Books.

Zan, Brown, Evan \& Hannula. (2006). Affect in mathematics education: An introduction. Journal of educational studies in mathematics, 63, 113-121. 